Review Article

\title{
Clothing manufacturing and exporting countries of the World: a review
}

\begin{abstract}
The aim of this paper is to discuss about the textiles and clothing manufacturing and exporting countries of the world. This paper has some objectives such as introducing the applications of spandex fabrics, discussing highest clothing importers, and detailing recent textile trade expansion countries etc. The textiles and clothing industries are categorized by changeable mandate, short product life sequences, rapid response time, enormous product diversity, and an unstable, unyielding, and intricate supply chain structure. The textile and clothing industries subsidize meaningfully towards the national budget of many countries. Although the clothing industry is worldwide in nature, the engineering facilities from established countries are flowing to developing countries to lessen the labor fees. Even in these developing countries, the clothing industries are fronting the greatest experiments in spite of the inexpensive labor cost, due to the petite production life-cycle, high instability, low expectedness, high level of instinct purchase and the quick market reaction. To diminish the cost of manufacture, the clothing industries in developing countries are rather concentrating on sourcing of inexpensive raw materials and minimizing transfer cost than labor efficiency due to the obtainability of inexpensive labor.
\end{abstract}

Keywords: elastic clothing; textile exporters; annual revenue; highest export countries; clothing manufacturer; investments
Volume 6 Issue 5 - 2020

\author{
Shaikh Md Mominul Alam,' Shariful Islam, ${ }^{2}$ \\ 'Department of Textile Machinery Design and Maintenance, \\ Faculty of Science and Engineering, Bangladesh University of \\ Textiles, Tejgaon, Dhaka 1208, Bangladesh \\ ${ }^{2}$ Department of Textile Engineering, Faculty of Science and \\ Engineering, City University, Dhaka, Bangladesh
}

Correspondence: Shariful Islam, Department of Textile Engineering, Faculty of Science and Engineering, City University, Dhaka, Bangladesh.Email engrsitareq@gmail.com

Received: June 24, 2020 | Published: September 22, 2020

\section{Introduction}

There is a great importance of this paper in the field of textiles and clothing business. The common spandex trade plants are situated in China. In the earlier, most of these cloths were created in the USA, but condensed labor charges have driven the production of many different types of fabrics to China over the last few periods. ${ }^{1}$ A new revitalization in the U.S. engineering frugality may control over a return of spandex manufacture to American coastlines, but whatsoever the case may be, market rumors plan to upcoming spandex manufacture. ${ }^{2}$ While many kinds of synthetic materials have lost admiration in recent years, there is no diminish of spandex that means this types of fabrics will endure to enjoy amplified growth until at least new coming decays. ${ }^{3}$

As like as other polymer materials, spandex fibers are created from repeating chains of monomers those are alleged together in an acid. ${ }^{4}$ Initial of the spandex expansion procedure, it was predictable that, this product is extremely heat-resistant and it is particularly heat-sensitive fabrics as like as nylon and polyester, which are enhanced when joint with spandex cloths. ${ }^{5}$ Stretchiness of elastic cloths proximately made it desired everywhere the sphere, and the acceptance of this fabric perseveres to this day. ${ }^{6}$

It is existing in so many kinds of clothing that virtually every customer owns at least one article of dress that covers spandex, and it's doubtful that this fabric's acceptance will reduction in the near prospect. ${ }^{7}$ Undesirably, elastane has a meaningfully negative environmental influence after it is announced into the customer market. Spandex cloth is made by many diverse international companies. ${ }^{8}$ Some of these companies, such as DuPont, have workshops in lots of different republics, but others may be contained to one country in individual. Figure 1 shows the textile importers of the world.

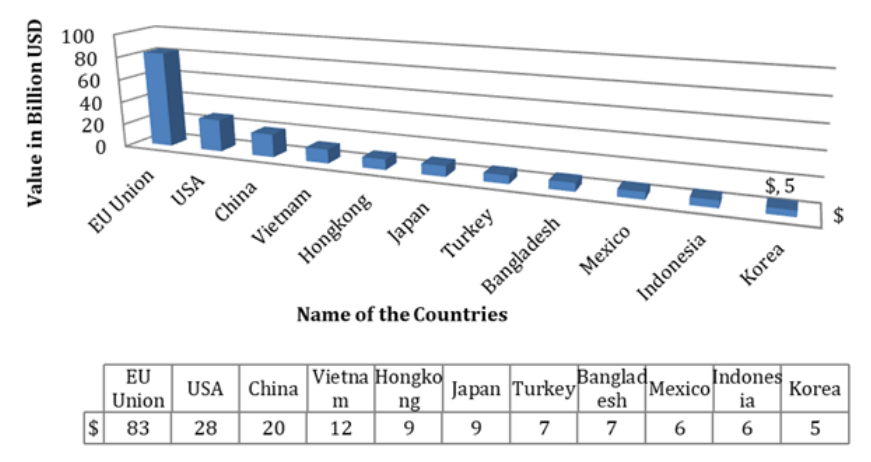

\section{Figure I Textile importers of the World.}

As spandex is a completely synthetic fiber, no organic constituents are used to create this substantial. In its place, all of the essential parts of this fiber are prepared in a laboratory setting, and they are then joined under precise inducements to generate spandex fabric. ${ }^{9}$ In the years since the creation of elastane, a number of diverse procedures for making this fabric have arisen. Some of these systems are more effective than others, and by the passage of times, methods like retort spinning, melt extrusion, and solution wet spinning processes have frequently been rejected. ${ }^{10}$

Nearly 95 in a hundred of the world's spandex are now prepared with a technique called solution dry spinning, and it is this engineering progression that we will scrutinize in aspect. ${ }^{11}$ For starting the spandex cloth manufacturing process, a constituent called macro glycol is assorted with a di-iso-cyanide monomer under definite temperature and compression. ${ }^{12}$ The heat and pressure settings must be meticulous 
to create the wanted results and the macro glycol and di-iso-cyanide monomer must also be in a proportion estimated to $6: 3 .{ }^{13}$

If the right settings are smeared, a constituent named a prepolymer is created, and this product is then used in the residue of the manufacturing process. ${ }^{14}$ Once it has created, the pre-polymer is supposed to di-amine acid, and a chemical response called chain extrusion reaction is started. Textile and clothing industries are one of the reckless mounting industries, providing occupation to millions of people. ${ }^{15}$ These productions units are dependent on the use of poisonous chemicals for dispensation of textiles, which pointers to enlarged environmental pollution and public anxiety. ${ }^{16}$

The resultant material is highly viscid, and it must be thinned with a solvent before it can transfer on to the following stage. ${ }^{17}$ When it is thin enough to react with, the pre-polymer is laden into a machine called a fiber manufacturing cell or a tubular spinning cell. Inner side of this machine there is an expedient called a spinneret, which has lots of tiny pigpens. ${ }^{18}$ As the fiber manufacturing cell rotates, the prepolymer solution is enforced through these holes, and it receipts on the form of threads of fabric. ${ }^{19}$

These threads are tranquil in a fluid state when they arise from the spinneret, and they are then supposed to frenzied solvent gas and nitrogen to condense them into a dense stage. ${ }^{20}$ These hard fibers are then strapped out of the tubular spinning cell, and when they are exposed to pressed air, they procedure into warped strands. ${ }^{21}$ This compacted air can form threads of many diverse sizes. Finally, the spandex fiber is absorbed in a finishing agent containing the magnesium stearate or a parallel substance. Once it is laden onto a reel, it is set to weave a cloth. ${ }^{22}$

\section{Application of spandex fabrics}

Elastic fabrics or spandex fabrics are used in any customer or manufacturing application in which springiness is preferred. As, its commencement this type of cloths have become more and more prevalent, and these days, it is available in hundreds of various kinds of clothing, and it is applied by clients all over the world. In some areas, spandex fabric may be applied to create extremely flexible or fully form decent costumes. ${ }^{23}$ Conversely, this fabric is comparatively exclusive, and these types of outfits are quite expensive to the customers of experts who use them. In its place, it's much more communal to see spandex fabric woven into other kinds of fabrics. ${ }^{24}$ Figure 2 shows the world's textile contributions.

\section{Export (\%)}

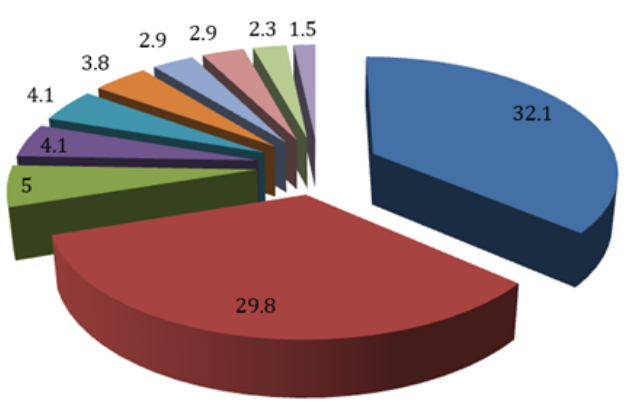

- W.EU
= China
= USA
= India
= Korea
= Turkey
= Japan
= Pakistan
= UAE
= Indonesia

Figure 2 World's textile contribution.

If spandex fabrics are used with cotton fibers, they become much elastic, and spandex can also be applied to add elasticity to conventionally inflexible fabrics such as polyester. ${ }^{25}$ Although small types of this fabric are further to mingled with other textile products, these fabrics become much stretcher; as spandex can bounce up to eight times than its original measurement. ${ }^{2}$ Elasticity conveyed to this fabric to other fabrics can be resolute by dividing this stretching latent by the percentage in which it is comprised in clothing. ${ }^{27}$

Usual use of spandex in fabrics is particularly for body fitting garments used in sportswear. For example, it is involved in many kinds of underclothing for men and women, and even if it isn't existent in the shell fabric of an underclothing garment; it is almost constantly existent in the waistband. ${ }^{28}$ Actually, spandex fabric is initiate in the waistbands of almost each type of stretch clothing. Spandex is also recycled in comparatively high percentages in cotton and wool smacks. ${ }^{29}$ Consuming this fabric in smacks helps these clothes to keep on your bases, and it also eases the exhausting and elimination of socks.

This fabric is extremely common in casualwear. In most kinds of muscular pursuits, wearing garments that gallop adjacent to the skin. ${ }^{30}$ Spandex fabric is applied in beachwear, bicycling apparel, and kinds of fashion those are applied in modest team sporting. Spandex cloths are also used in industrial applications..$^{31}$ For example, it is used in the movie industry to make gesture capture outfits, which are unusual kinds of bodysuits that performers attire in front of green monitors. ${ }^{32}$ Spandex creates it informal to make realistic 3D letterings by creating ensembles ride close to the figures of performers. ${ }^{33}$

Because of its innovation and the comparatively protracted production procedure used to create it, spandex fabric demands a comparatively high market charges. ${ }^{34}$ It is more exclusive than polyester and nylon, and it is also typically more costly than organic cloths like wool and cotton.

As elastane is normally recycled in small amounts in apparel, however, this amplified price does not habitually make itself ostensible at the customer level. ${ }^{35}$ The more the spandex fibers are used in garments the more the cost of the fabrics are. For example, definite types of riding gear and expert dance clothes that comprise high levels of spandex are pretty expensive. ${ }^{36}$

\section{Textiles and clothing manufacturing countries}

The worldwide trade of clothing and textile products is no longer administrated by shares, when the contract on textiles and fashion was ended. ${ }^{37}$ Presently, the international trade has been administered by lawmaking within the polygonal trading scheme, which assisted in the stable increase of importations from countries with low employment expenses. ${ }^{38}$ When client fulfillment is painstaking, the speed of replacement comes into play. Thus, the countries with propinquity are more reasonable for those goods where replacement is significant, and these financial factors will deepen. ${ }^{39}$ Figure 3 shows the global textiles market for clothing, fashion and sportswear.

Hence, cost and positions are the two drivers supporting the sourcing choices. Advanced countries like the US, Australia and the UK are facing a firm deterioration of native textile and clothing production. ${ }^{40}$ The states in Asia are the foremost producers of fashion items everywhere in the world. Amongst the Asian nations, China endures to be the foremost exporter of textiles and fashion items. ${ }^{41}$ Its segment in world spreads amplified to $30 \%$ for cloths and to $40 \%$ for textiles. The European Union and the USA continue the chief markets for apparel, accounting for $35 \%$ and $22 \%$, correspondingly, of world 
ingresses in 2012. Besides, a mainstream of the Asian nations are among the prominent exporters of dress items. ${ }^{42}$

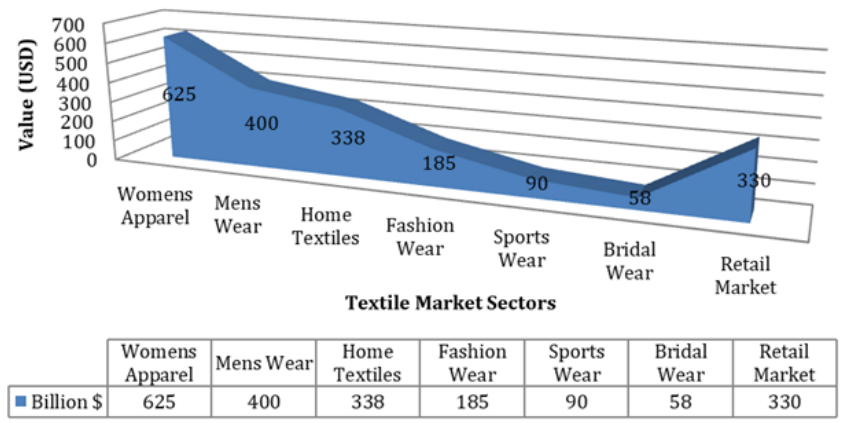

Figure 3 Global textiles market for clothing, fashion and sports wear.

Sustainability is a expression often used in relative to environmental matters. Defeat of biodiversity, releases of greenhouse gases, and water contamination are all issues usually known as sustainability contests. ${ }^{43}$ Though, issues nearby the environment establish a very significant feature of sustainability. Consequently, when thoughtful about how to extent and communicate clothing sustainability, we must be cautious not to focus exclusively on sustainability as it narrates to environmental matters. ${ }^{44}$

Reliable sustainability within the clothing industry is only conceivable when one deliberates how economic welfares to the industry can be justifiably shared through a society and how the business can manner production while meeting the basic requirements, empowering, and guaranteeing the well-being of all investors. ${ }^{45}$ On typical, apparel industrial labors are paid two-thirds of the hourly salary earned by workforces in other manufacturing productions. ${ }^{46}$

As part of the literature lecturing these subjects, academics note an amplified need for checking factories for acquiescence with social standards, counting better methods for journalism and deciding issues of exploitation, allowing workers, and allowing employees the right to cooperative negotiating. ${ }^{47}$ Additionally, environmental misuses in the production, distribution, and ingesting of AT goods are of swelling apprehension in the supply chain. ${ }^{48}$

From the engineering of fibers to the customer care and disposal of clothes, all actions damage the environment. Procedures within the supply chain necessitate large water and energy inputs and comprise the use of toxic substances in the production of properties. ${ }^{49}$ The removal of these harmful substances and other wildernesses are also environmental anxieties relevant to the diligence. Textile industry is booming and increasing at high speed expertise. ${ }^{50}$ Figure 4 shows the destination of Bangladeshi clothing materials to the world.

The textile or Clothing industry's main aim is to create up-to-date and fashionable design and production of textile materials including Yarn, cloths and fashion wear. ${ }^{51}$ Parallel to all other nations' Indian and Chinese clothing markets shown vigorous development whereas Bangladesh is also evolving as foremost manufactures of textile in the world. ${ }^{52}$ Four Asian countries such as China, Bangladesh, Vietnam and India are the largest clothing exporters in the world. ${ }^{53}$

China relics the most prevalent part of 21\%, Bangladesh and India both are second position at $14 \%$, where Vietnam arises right in arrears at $12 \%$. Though all four countries have a well improved clothing industry, each has an exclusive business weather that may be more or less appropriate for our manufacturing requirements. ${ }^{54}$ Low-cost employment is surely a key factor in selecting a supplier for industrial apparels. But don't markdown other worries that can disturb your quality and deliverability, like employment output and substructure progress. ${ }^{55}$

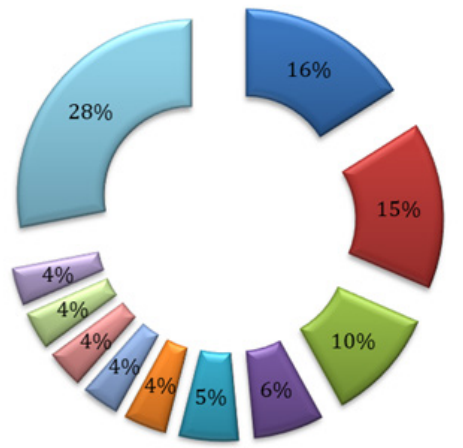

IUSA

a Germany

$\square \mathrm{UK}$

घpain

⿶. France

IItaly

๑Japan

๑Canada

$\square$ Netherlands

$\square$ Poland

\Others

Figure 4 Destination of Bangladeshi clothing materials to the World.

\section{Highest exporting countries of the world}

China is one of the largest manufacturer and exporter of textiles and clothing items in the world with an export income of 260 billion USD. ${ }^{56}$ China is a country that is manufacturing every type of textiles and clothing items including fibers, yarns, fabrics, apparel, sportswear, fashion wear etc. This country is also exporting textile machine and machineries including spinning, weaving, knitting, dyeing, printing, finishing, testing equipment and apparel sewing machineries. ${ }^{57}$ The production capacity of China textile trade is more than half of the global market.

Textile and clothing manufacturing of Germany has an extended history of manufacturing, novelty, and elasticity. Germany is one of the main exporters of knitted clothing, manmade fiber, artificial yarn, and equipment with the export sum of 40 billion USD. ${ }^{58}$ The nation is world's $2^{\text {nd }}$ biggest textile exporter and well recognized for high excellence products and decorations of textile and clothing products in the world..$^{59}$ In the present time, it has distorted its production for low-cost high volume to high superiority goods.

Bangladesh is the $3^{\text {rd }}$ largest textiles and clothing manufacturer and exporter in the world among all the countries of the world with the annual turnover of 40 billion USD. ${ }^{60}$ This country exports woven, knit items and also yarns, fibers and all other textile facilities. The country's assets are low employment charge and vast workers. ${ }^{61}$ Improvement expertise and good superiority merchandises have paying attention of many major universal selling marques to Bangladesh. ${ }^{62}$ The upright abilities of Bangladesh that aids to make sure more limpidity and direction in their team work. The textiles and clothing factories of Bangladesh are expanding very fast with the production order of value added materials of renowned international brands. ${ }^{63}$ Figure 5 shows the textiles and clothing manufacturing countries of the world.

Vietnam is an expanding textile manufacturer of recent time with an annual turnover of 38 billion USD. ${ }^{64}$ The country's chief attention is manufacturing substances with high attractiveness in the overall market and refining its garment and textile networking system. ${ }^{65}$ Vietnam's textile and apparel ingesting in the both national and international market create profounder inroads into the clothing bazaar. 


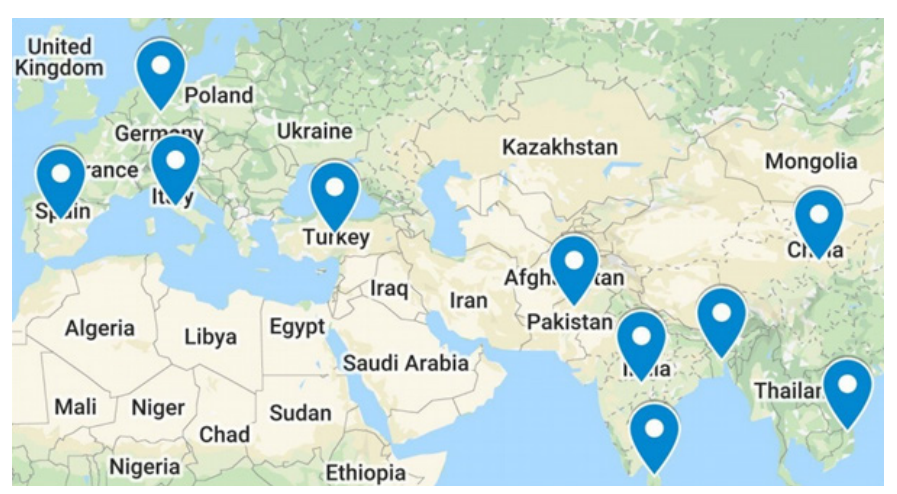

Figure $\mathbf{5}$ Textiles and clothing manufacturing Countries of the World.

India is one of the biggest textiles and clothing manufacturers and exporters with the annual turnover of 38 billion USD ${ }^{66}$ India has huge production capabilities of every types of items like formal wear, casual, sportswear, fashion wear etc. the county is in $5^{\text {th }}$ position for its wonderful manufacturing and exporting capability. ${ }^{67}$

Italy is next to India, which is also a big textile and clothing manufacturer and exporter with the annual turnover of 36 billion USD. ${ }^{68}$ This country has strength for the production of textiles, clothing, machines etc.

Textile and clothing industry of Turkey has a significant character in world textile profession with the competence to come across with the extraordinary standard and a comprehensive range of merchandises. Turkey has an annual turnover of 27 billion USD. ${ }^{69}$

USA is the $8^{\text {th }}$ largest textiles and clothing manufacturer and exporter in the world amongst all the countries with the annual turnover of 27 billion USD. Hong Kong is the $9^{\text {th }}$ largest textiles and clothing manufacturer and exporter in the world among all the countries of the world with the annual turnover of 20 billion USD. $^{70}$ This country exports woven, knit items and also yarns, fibers and all other textile facilities. ${ }^{71}$

Spain is the $10^{\text {th }}$ renowned manufacturer and exporter in the world with its quality clothing items. The annual turnover of this country is 20 billion USD. ${ }^{72}$ This country has a well reputed goodwill to exports the sophisticated quality products. Presently, these countries are in the driving seats for the textiles and clothing markets across the world. ${ }^{73}$

\section{Conclusion}

Recently the world has seen the rise of textile and clothing industry with the increased demand for daily clothing items all over the universe. Although some of the clothing producers still persist in the developed countries, they are belligerent for existence due to low productivity. It is seen from the paper that, European Union is the highest textile importers of the world with a turnover of 83 billion of USD where Korea was the lowest with 5 billion of USD. It is also seen that in world's textile contribution Indonesia holds the highest position with $29.8 \%$ of textile's export goods. In the world's textile market women's apparel holds the highest position with 625 billion of USD. Bangladesh exports the highest amount that is $28 \%$ of textile products to France. In the worldwide economic situation, the benefit of manufacturing dress items nearby over engineering abroad comprises intimacy to the market and the aptitude to respond to fashion variations faster than the distant contestants. Though, the local producers are slowly reducing the production and concentrating on performing only the commercial functions intricate in clothing manufacturing, which contain buying raw ingredients, designing dresses and accessories, making samples and ordering for the production, circulation and marketing of the complete product. Worldwide dress production has now removed to the developing countries and is more and more centralizing in the nations like China, Bangladesh, India, Pakistan etc. With the increasing demand caused by the widespread applications in the downstream productions, the non-woven section is predictable to observer a faster development rate among the worldwide textile business concluded by the next several years.

\section{Acknowledgments}

None.

\section{Funding}

None.

\section{Conflicts of interest}

The authors have no conflicts of interest regarding the publication of this paper.

\section{References}

1. Haseeb M, Haouas I, Nasih M, et al. Asymmetric impact of textile and clothing manufacturing on carbon-dioxide emissions: Evidence from top Asian economies. Energy. 2020;196:117094.

2. Chan EMH, Ho CKD, Yip TL, et al. The belt and road initiative's impact on textile and clothing supply chains in Asia: Views from Hong Kong industrial stakeholders. Belt and Road Initiative-Collaboration for Success. 2020:51-61.

3. Islam S, Haque Md, Arifuzzaman Md, et al. Identifying the causes of the spandex breakage of woven garments and its solutions. Advance Research in Textile Engineering. 2020;1(1):1-24.

4. Sondhi S. Sustainable approaches in effluent treatment: Recent developments in the fashion manufacturing. Sustainable Technologies for Fashion and Textiles. 2020:327-341.

5. Islam S, Parvin F, Urmy Z, et al. A study on the human health benefits, human comfort properties and ecological influences of natural sustainable textile fibers. European Journal of Physiotherapy and Rehabilitation Studies. 2020;1(1):1-24.

6. Setyorini D, Budiono B. The impact of tariff and imported raw materials on textile and clothing export: evidence from the United States market (No. 202004). Department of Economics, Padjadjaran University; 2020.

7. Parvin F, Islam S, Urmy Z, et al. A study on the textile materials applied in human medical treatment. European Journal of Physiotherapy and Rehabilitation Studies. 2020;1(1):26-51.

8. Chae Y, Hinestroza J. Building circular economy for smart textiles, smart clothing, and future wearables. Materials Circular Economy. 2020;2:1-4.

9. Shariful Islam, Shahria Ahmed. Attaining optimum values of the colorfastness properties of sustainable dyes on cotton fabrics. FIBRES \& TEXTILES in Eastern Europe. 2020;144(6):1-8.

10. Bischoff C, Wood G. Survival and outsourcing in the South African clothing and textiles industry: The changing fortunes of ClothTran. Case Studies in Work, Employment and Human Resource Management; 2020.

11. Shariful Islam SM, Alam M, Akter S. Detecting the color strength, color intensity, chromophore extent and colorfastness properties of dyed cotton fabrics. International Journal on Emerging Technologies. 2020. 
12. Hack-Polay D, Rahman M, Billah M, et al. Big data analytics and sustainable textile manufacturing: Decision-making about the applications of biotechnologies in developing countries. Management Decision; 2020.

13. Shariful Islam SM, Alam M. The significance of medical textiles in COVID-19 treatment. Biomedical Journal of Scientific and Technical Research. 2020.

14. Morgan L, Matthews J, Shen J, et al. Laser peri-dyeing for agile textile design: implementing laser processing research within the textile industry. 2020.

15. Islam S, Parvin F, Urmy Z, et al. A study on the solutions of environment pollutions and worker's health problems caused by textile manufacturing operations. Biomedical Journal of Scientific and Technical Research. 2020 .

16. Majumdar A, Sinha SK, Shaw M, et al. Analysing the vulnerability of green clothing supply chains in South and Southeast Asia using fuzzy analytic hierarchy process. International Journal of Production Research. 2020:1-20.

17. Islam S, Parvin F, Urmy Z, et al. The symptoms, contagious process, prevention and post treatment of covid-19. European Journal of Physiotherapy and Rehabilitation Studies. 2020.

18. Belso-Martinez JA, Tomás-Miquel JV, Expósito-Langa M, et al Delving into the technical textile phenomenon: networking strategies and innovation in mature clusters. The Journal of The Textile Institute. 2020;111(2):260-272

19. Shariful Islam SM, Alam M, et al. Achieving optimal shrinkage of cotton spandex woven fabrics by apposite heat setting temperature. Advance Research in Textile Engineering. 2020.

20. Kalayci S. The role of trade liberalization and gdp on textile \& clothing export: the case of Japan. Academic Studies in Social, Human and Administrative Sciences. 2020. 271 p

21. Shariful Islam SM, Alam M, Akter S. Reviewing the sustainability of natural dyes. Advance Research in Textile Engineering. 2020.

22. Morita AM, Moore CCS, Nogueira AR, et al. Assessment of potential alternatives for improving environmental trouser jeans manufacturing performance in Brazil. Journal of Cleaner Production. 2020;247:119156.

23. Shariful Islam SM, Alam M, Akter S. Investigation of the colorfastnes properties of natural dyes on cotton fabrics. Fibers and Textiles. 2020;27(2):96-109.

24. Wazna ME, Ouhaibi S, Gounni A, et al. Experimental and numerica study on the thermal performance of alternative insulation materials based on textile waste: A finite-difference approach. Journal of Industrial Textiles. 2020;49(10):1281-1303.

25. Shariful Islam SM, Alam M, Akter S. Identifying the values of whitenes index, strength and weight of cotton spandex woven fabric in peroxide bleaching of different concentration. Fibers and Textiles. 2019;26(4):96109.

26. Haseeb M, Haouas I, Nasih M, et al. Asymmetric impact of textile and clothing manufacturing on carbon-dioxide emissions: Evidence from top Asian economies. Energy. 2020;196:117094.

27. Islam S. Attaining optimum strength of cotton-spandex woven fabric by apposite heat-setting temperature. Journal of The Institution of Engineers (India): Series C, Springer. 2019;100(4):601-606.

28. Chan EMH, Ho CKD, Yip TL, et al. The belt and road initiative's impact on textile and clothing supply chains in Asia: Views from Hong Kong industrial stakeholders. Belt and Road Initiative-Collaboration for Success Springer, Singapore. 2020:51-61.

29. Islam S, Mominul Alam SM, Akter S. The consequences of temperature on the shrinkage properties of cotton spandex woven fabric. Journal of Textiles and Polymers. 2019;7(1):25-29.
30. Chan MHE, Hob CKD, Yipc TL, et al. Evaluating the impact of the belt and road initiative for textile and clothing companies in Asia. Journal of International Conference Proceedings. 2019;2(1):20.

31. Islam S, Ahmed S. Investigation of the mechanical properties of thermal bonded nonwoven composite produced of blends with sustainable fibers. Advance Research in Textile Engineering. 2019;4(2):1039.

32. Guan $\mathrm{Z}, \mathrm{Xu} \mathrm{Y}$, Jiang $\mathrm{H}$, et al. International competitiveness of Chinese textile and clothing industry-a diamond model approach. Journal of Chinese Economic and Foreign Trade Studies. 2019.

33. Islam S, Nasif Chowdhury JY, Arifuzzaman FI, et al. Detecting the physical properties of thermal bonded nonwoven fabrics. Trends in Textile Engineering and Fashion Technology. 2019;5(2):1-18.

34. Sondhi S. Sustainable approaches in effluent treatment: Recent developments in the fashion manufacturing. Sustainable technologies for fashion and textiles. 2020:327-341.

35. Islam $\mathrm{S}$, Tasnim $\mathrm{N}$, Islam $\mathrm{T}$. Investigation of the change of the shrinkage properties in contradiction to the change of the composition of cotton polyester spandex denim fabrics. Journal of Textile Engineering and Fashion Technology. 2019;5(3):163-168.

36. Sondhi S. Sustainable approaches in effluent treatment: Recent developments in the fashion manufacturing. Sustainable technologies for fashion and textiles. 2020:327-341

37. Islam S, Yasmin J, Kanon R. Detecting the spandex injuries and therapies of stretched garments. Journal of Textile Engineering and Fashion Technology. 2019;5(3):170-175.

38. Cueto G, Caldas Y, Viacava G, et al. August. Waste reduction model in a small clothing company-umbrella model. International Conference on Human Interaction and Emerging Technologies. 2019:994-1000.

39. Shariful Islam, Shaharia Ahmed, Md Arifuzzaman, et al. Relationship in between Strength and polyester content percentage of cotton polyester blended woven fabrics. International Journal of Clothing Science. 2019;6(1):1-6.

40. Agrawal TK, Pal R. Traceability in textile and clothing supply chains: Classifying implementation factors and information sets via Delph study. Sustainability. 2019;11(6):1698

41. Islam Shariful, Yasmin Jarin, Alam Syed Toufiqul, et al. Identifying the strength properties of cotton polyester blended woven fabrics of different fiber content. Research Journal of Material Sciences. 2019;7(2):1-6.

42. Lin TA, Chuang YC, Lin JY, et al. Weaving carbon fiber/recycled polypropylene selvages to reinforce the polymer-based protective composite fabrics: Manufacturing techniques and electromagnetic shielding effectiveness. Polymer Composites. 2019;40(S2):E1910E1917.

43. Islam S, Chowdhury S, Akter S. The experiential analysis of woven fabric for reproduction. Journal of Textile Science and Technology. 2018;4(01):18

44. Nyoni AB, Nkiwane LC, Gonde P. The impact of imported new and second-hand clothing on the Zimbabwe textile and clothing industry. Ethiopian Journal of Textile and Apparel. 2019;1(1).

45. Islam S, Alam SMM, Akter S. Identifying a suitable heat setting temperature to optimize the elastic performances of cotton spandex woven fabric. Research Journal of Textile and Apparel. 2018;28(2):128.

46. Kumar PS, Yaashikaa PR. Recycled fibres. Sustainable Innovations in Recycled Textiles. 2018:1-17.

47. Islam S, Alam SMM. Investigation of the acoustic properties of needle punched nonwoven produced of blend with sustainable fibers. International Journal of Clothing Science and Technology. 2018;52(4):1-34. 
48. Pal R, Harper S, Vellesalu A. Competitive manufacturing for reshoring textile and clothing supply chains to high-cost environment. The International Journal of Logistics Management. 2018.

49. Shariful Islam, Shilpi Akter, Sutapa Chowdhury. The experiential analysis of woven fabric for reproduction. Journal of Textile Science and Technology. 2018.

50. Kukreja P. Skill mismatch and returns to education in manufacturing: A case of India's textile and clothing industry. 2018.

51. Shariful Islam, Zakia Urmy, Amirul I, et al. A comparative study on different dimensions of CAD. Trends Textile Eng Fashion Technol. 2018;1(1).

52. Gwangwava E. Enhancing corporate performance of the textile and clothing manufacturing sector through strategic cost management accounting techniques. Doctoral dissertation, Chinhoyi University of Technology; 2018.

53. Islam $\mathrm{S}$. Textile CAD analysis for warp and weft patterning. $J$ Textile Sci Eng. 2018;8:332.

54. Fu B, Shu Z, Liu X. Blockchain enhanced emission trading framework in fashion apparel manufacturing industry. Sustainability. 2018;10(4):1105.

55. Iacobucci D, Perugini F. Changing models of innovation in the EU textile and clothing industry. L'industria. 2018;39(2):173-194.

56. Bullón J, González Arrieta A, Hernández Encinas A, et al. Manufacturing processes in the textile industry. Expert Systems for fabrics production. 2017.

57. Lau YY, Chan MH, Nguyen HO. Assessing the displacement effect of exports with gravity trade model: China's textile and clothing case and OBOR implications. Journal of International Logistics and Trade. 2017;15(1):19.

58. Costa Maia L, Alves AC, Leão CP, et al. Validation of a methodology to implement lean production in textile and clothing industry. ASME 2017 International Mechanical Engineering Congress and Exposition. American Society of Mechanical Engineers Digital Collection. 2017.

59. Sanatgar RH, Cayla A, Campagne C, et al. Manufacturing of polylactic acid nanocomposite 3D printer filaments for smart textile applications. IOP Conference Series: Materials Science and Engineering. 2017;254(7):072011.

60. Debnath SR, Islam M. A study on current perspective of supply chain management of textile \& clothing industry of Bangladesh. Relevant To Future Demand. International Journal of Scientific \& Engineering Research. 2017;8(9):430-439.

61. Resta B, Gaiardelli P, Pinto R, et al. Enhancing environmental management in the textile sector: an organisational-life cycle assessment approach. Journal of Cleaner Production. 2016;135:620-632.
62. Hasan KF, Mia MS, Rahman MM, et al. Role of textile and clothing industries in the growth and development of trade \& business strategies of Bangladesh in the global economy. International Journal of Textile Science. 2016;5(3):39-48.

63. Debnath S. Natural fibres for sustainable development in fashion industry. Sustainable Fibres for Fashion Industry. Singapore: Springer; 2016:89-108.

64. Mehra B, Bhattar S, Saxena S, et al. Garden swing hanging dream chair lounger chaise arc stand air porch swing hammock chair-50webs.com. Journal of Laboratory Physicians. 2016;8(1):36.

65. Top 10 exporting countries of textile and apparel industry. Fiber2Fashion; 2019.

66. Howard, E.K., 2016. The External Bottlenecks of the Ghana Textile Industry. Ghana Journal of Science, Technology and Development, 4(2), pp.11-28.

67. Drake EL. An investigation of bloodstains on dark surfaces and under paint with the Foster and Freeman Crime-Lite 82S Infrared and camera. Doctoral dissertation, Los Angeles: California State University; 2016.

68. Chakrabarti S, Banerjee P. Preparation and characterization of multifunctional cotton fabric by coating with sonochemically synthesized zinc oxide nanoparticle-flakes and a novel approach to monitor its self-cleaning property. The Journal of The Textile Institute. 2015;106(9):963-969.

69. Khan ZR, Rodrigues G. Human before the garment: Bangladesh tragedy revisited. Ethical manufacturing or lack thereof in garment manufacturing industry. World. 2015;5(1):22-35.

70. Tresnadi C, Sachari A. Identification of values of ornaments in Indonesian batik in visual content of Nitiki game. Journal of Arts and Humanities. 2015;4(8):25-39.

71. Eryuruk SH. Life cycle assessment method for environmental impact evaluation and certification systems for textiles and clothing. Handbook of Life Cycle Assessment (LCA) of Textiles and Clothing. Woodhead Publishing; 2015:125-148.

72. Kapelko M, Lansink AO. An international comparison of productivity change in the textile and clothing industry: a bootstrapped Malmquist index approach. Empirical Economics. 2015;48(4):1499-1523.

73. Shih WYC, Agrafiotis K. Competitive strategies of new product development in textile and clothing manufacturing. The Journal of the Textile Institute. 2015;106(10):1027-1037. 